\title{
The effectiveness of silicon-containing preparations as fertilizers for sugar beet
}

\author{
$A$ Kulikova $^{1, *}, V$ Isaichev $^{1}, E$ Yashin $^{1}$, and $G$ Saidyasheva $^{2}$ \\ ${ }^{1}$ P.A. Stolypin Ulyanovsk State Agrarian University, Ulyanovsk, Russia \\ ${ }^{2}$ Ulyanovsk Research Institute - an affiliate of the Samara Federal Research Center of the Russian \\ Academy of Sciences, Ulyanovsk Region, Ulyanovsk District, settlement of Timiryazevsky, Russia
}

\begin{abstract}
The paper presents the results of trials of silicon-containing preparations ADK (amorphous silicon dioxide) and Risilika (pyrolysate of rice husks and straw) as fertilizers for sugar beet in field experiments. The experimental design included seven options: 1 . Control; $2^{\text {nd }}, 3^{\text {rd }}$ and $4^{\text {th }}$ options with the application of ADK into the soil at doses of 100, 250, 500 $\mathrm{kg} / \mathrm{ha} ; 5^{\text {th }}, 6^{\text {th }}$ and $7^{\text {th }}$ options - Risilika in appropriate doses. Both preparations had a positive effect on the nutrient regime of the soil (the content of available compounds of nitrogen, phosphorus, potassium and silicon), yield and quality of sugar beet roots. The yield of roots when using ADK as a fertilizer increased by 3.32-6.52 t/ha (14-27\%), Risilika by $1.92-4.75 \mathrm{t} / \mathrm{ha}(8-19 \%)$. The yield increases as a result of raising preparation doses. At the same time, the increase in sugar content provided an additional yield of more than 1 ton of sugar per hectare.
\end{abstract}

\section{Introduction}

Back in 1862, Julius Sachs, one of the first researchers of plant nutrition, paid attention to the role of silicon and wrote the following ".... whether silicic acid is a substance indispensable for those plants that contain silicon, whether it takes part in metabolic processes and how the life of a plant depends on the uptake of silicon". More than 155 years have passed since then, a great number of works have been published on the role of silicon in the "soil-plant" system, including those summarized in the corresponding reviews [1-5], but these issues still remain topical today.

The total silicon content in soils is high (from 20 to $49 \%$ depending on the type of soil and its granulometric composition), in which it is present in the composition of minerals: quartz, feldspars, vermiculite, smectite, kaolin, orthoclase and other compounds. Crystalline silicon compounds are chemically stable and practically insoluble in water, however, in addition to crystalline compounds in all natural objects, including soil, there are water-soluble forms of it in the form of monosilicic $\left(\mathrm{H}_{4} \mathrm{SiO}_{4}\right)$ and polysilicic acids. The latter are a source of silicon for plants, the need for which is comparable to the content of available phosphorus, potassium, calcium and is $0.1-0.6 \mathrm{millimol} / 1$ [6].

\footnotetext{
*Corresponding author: agroec@yandex.ru
} 
Plants take up silicon mainly in the form of monosilicic acid and silicate ion [7]. Taking account of its annual removal of 100-700 kg / ha [3], and soil reserves of available forms of this element do not exceed $20 \mathrm{~kg} / \mathrm{ha}$ [4], in all the soils used for agricultural production, the deficit of available silicon is growing. The latter necessitates the use of silicon fertilizers and, not accidentally, their number is growing throughout the world [5, 8-12]. At the same time, both natural materials (high-siliceous rocks: diatomite, zeolite, gaize, bergmeal) and synthetic silicon-containing preparations are offered as fertilization substances (silaktiv, siliplant, kremnevite, pronixila - Russia; Quantum - Aquasila - Ukraine; Kelik - K - Si , controlfit - Si - Spain) and growth stimulants containing silicon in organic form: mival, mival-agro, TES, cherkaz, energiya-M, epost [10]. The LLC "Resilika" (Russia) offered 2 silicon-containing preparations - ADK and Risilika, and this work is devoted to the study of their effectiveness as silicon fertilizers of sugar beet.

\section{Materials and research methods}

The cultivation of sugar beet using silicon-containing preparations ADK and Risilika was carried out in 2018 by the LLC "Zavolzhsky", in Cherdaklinsky district, Ulyanovsk region. The research objects were the following:

- silicon-containing preparation ADK - amorphous silicon dioxide with the silicon content of $17 \%$;

- silicon-containing preparation Risilika - pyrolysate of rice husks and straw;

- sugar beet - "Expert";

- leached medium loamy chernozem of medium thickness with the humus content in the arable layer $(0-30 \mathrm{~cm}) 4.5 \%$, available phosphorus and potassium 174 and $161 \mathrm{mg} / \mathrm{kg}$, respectively;

- pHKCl 6.4 units.

The experiment design consisted of seven options:

1. Control; 2. ADK $100 \mathrm{~kg} / \mathrm{ha} ; 3$. ADK $250 \mathrm{~kg} / \mathrm{ha} ; 4$. ADK $500 \mathrm{~kg} / \mathrm{ha} ; 5$. Risilica $100 \mathrm{~kg} / \mathrm{ha} ; 6$. Risilica $250 \mathrm{~kg} / \mathrm{ha} ; 7$. Risilica $500 \mathrm{~kg} / \mathrm{ha}$.

The preparations were introduced prior pre-sowing cultivation.

The area of the record plot is $13.5 \mathrm{~m}^{2}$ ( 6 rows of $5 \mathrm{~m}$ long), the layout of plots is randomized, the experiment was repeated 4 times, the harvest is recorded on each plot.

All the analyses of soil and plant samples were carried out in accordance with the current standards, regulatory and technical documentation in the accredited laboratory of the FSBI Agricultural agrochemical service "Ulyanovskaya".

The growing season was typical for the middle Volga region with an uneven distribution of precipitation and temperature: if there was a sufficient amount of precipitation in May $(25.2 \mathrm{~mm})$, then in June-July it was only 12.3 and $10.6 \mathrm{~mm}$ and in August - $18.8 \mathrm{~mm}$. The range of average daily temperatures was $16.2,18.5 ; 23.2 ; 20.1$ degrees respectively. Such growing conditions did not contribute to the formation of a higher yield of sugar beet.

\section{Results and their discussion}

Nutrient regime of the soil. Fertilization is one of the most powerful factors affecting the soil and its nutritional regime, therefore, it has an effect on the yield and produce quality of cultivated crops. The uptake of nutrients by sugar beet plants (as well as other crops) has its own specific features. The beginning of the growing season (up to the phase of the third pair of true leaves) is distinguished by the uptake of a small amount of nutrients. However, 
their presence in the root zone is very important, since the root system is still poorly developed. This period is especially critical in relation to phosphorus nutrition.

In the phase of leaf closing, intensive photosynthesis and increased uptake of nitrogen occur in interrow space, which contributes to the enhanced growth of vegetative organs and the formation of a powerful assimilation apparatus. Then, an increased accumulation of sugars takes place and plants during this period need more potassium.

Tables 1 and 2 show the content of main macronutrients in the arable layer of leached chernozem and the changes occurring in the soil after the introduction of silicon-containing preparations ADK and Risilika.

Table 1. Dynamics of the mineral nitrogen content $\left(\mathrm{N}-\mathrm{NH}_{4}+\mathrm{N}-\mathrm{NO}_{3}\right)$ in the soil under sugar beet, $\mathrm{mg}$ $/ \mathrm{kg}$.

\begin{tabular}{|c|c|c|c|c|c|}
\hline \multirow{2}{*}{ № } & \multirow{2}{*}{ Option } & \multicolumn{3}{|c|}{ Sugar beet development phases } & \multirow{2}{*}{$\begin{array}{l}\text { Average during the } \\
\text { growing season }\end{array}$} \\
\hline & & seedlings & closing of crop & $\begin{array}{c}\text { before } \\
\text { harvesting }\end{array}$ & \\
\hline 1 & Control & 10,17 & 10,34 & 5,20 & 8,57 \\
\hline 2 & ADK $100 \mathrm{~kg} / \mathrm{ha}$ & 10,49 & 10,80 & 5,29 & 8,86 \\
\hline 3 & ADK $250 \mathrm{~kg} / \mathrm{ha}$ & 10,60 & 11,06 & 5,28 & 8,98 \\
\hline 4 & $\begin{array}{l}\text { ADK } 500100 \\
\mathrm{~kg} / \mathrm{ha}\end{array}$ & 10,83 & 11,20 & 5,44 & 9,16 \\
\hline 5 & Risilika $100 \mathrm{~kg} / \mathrm{ha}$ & 10,82 & 11,25 & 5,53 & 919 \\
\hline 6 & Risilika $250 \mathrm{~kg} / \mathrm{ha}$ & 11,49 & 11,53 & 5,67 & 9,56 \\
\hline 7 & Risilika $500 \mathrm{~kg} / \mathrm{ha}$ & 8,56 & 11,63 & 5,74 & 8,64 \\
\hline & $\mathrm{LSD}_{05}$ & 0,28 & 0,19 & 0,12 & \\
\hline
\end{tabular}

Analysis of these tables shows that the use of silicon preparations helps to optimize the nutrition of sugar beet plants during the entire growing season of the crop. Already at the beginning of its introduction into the soil, preparations containing silicon in an accessible form had a certain positive effect on the nutrient regime of the soil, which is preserved till the end of the growing season, despite the increased nutrition of plants by them for the formation of yield. For instance, in the arable layer of soil under sugar beet, when ADK was introduced, the content of mineral forms of nitrogen increased by $0.32-0.66 \mathrm{mg} / \mathrm{kg}$ (3$6 \%$ ), Risilika - by $0.65-1.32 \mathrm{mg} / \mathrm{kg}$ ( 6-13\%). On average, during the growing season, their excess in relation to the control option was $0.29-0.59 \mathrm{mg} / \mathrm{kg}(3-7 \%)$ of ADK and 0.07$0.99 \mathrm{mg} / \mathrm{kg}(1-12 \%)$ of Risilika. It should be noted that the shift in the content of mineral nitrogen in the arable layer towards an increase from pyrolysate of rice husk and straw (Risilika) was greater than from ADK. The latter is undoubtedly due to a boost of the activity of soil microorganisms. 
A similar pattern was observed in the dynamics of the content of phosphorus and potassium compounds available to plants. However, if the advantage was for the option with the application of Risilica in respect to exchangeable potassium, then in respect to mobile phosphorus it was when ADK was applied, which, apparently, is due to a greater shift towards an increase in the amount of water-soluble silicon in the soil solution. There are the results of numerous studies in the scientific literature, which show an increase in the content of phosphorus available to plants in the soil when silicon fertilizers were applied [2, 4, 13-15]. The same applies to nitrogen: soluble silicon compounds increase the content of $\mathrm{NO}_{3}$ - and $\mathrm{NH}_{4}+$ by intensifying the microbiological activity of the soil [14].

Table 2. Dynamics of the content of available phosphorus and potassium in the arable layer under sugar beet, $\mathrm{mg} / \mathrm{kg}$ (in the numerator $\mathrm{P}_{2} \mathrm{O}_{5}$, in the denominator $-\mathrm{K}_{2} \mathrm{O}$ ).

\begin{tabular}{|c|c|c|c|c|c|}
\hline \multirow[t]{2}{*}{ Option } & \multicolumn{4}{|c|}{$\mathrm{P}_{2} \mathrm{O}_{5}$ and $\mathrm{K}_{2} \mathrm{O}$} & \multirow{2}{*}{$\begin{array}{l}\mathrm{SiO}_{2} \text { water- } \\
\text { soluble } \\
\text { during the } \\
\text { growing } \\
\text { season }\end{array}$} \\
\hline & seedling & closing of crop & $\begin{array}{c}\text { before } \\
\text { harvesting }\end{array}$ & $\begin{array}{l}\text { Average } \\
\text { during the } \\
\text { growing } \\
\text { season }\end{array}$ & \\
\hline Control & $173 / 159$ & $180 / 148$ & $156 / 138$ & $170 / 148$ & 32,6 \\
\hline ADK $100 \mathrm{~kg} / \mathrm{ha}$ & $178 / 161$ & $188 / 152$ & $160 / 143$ & $175 / 152$ & 33,4 \\
\hline ADK $250 \mathrm{~kg} / \mathrm{ha}$ & $181 / 167$ & $187 / 155$ & $159 / 145$ & $176 / 157$ & 35,5 \\
\hline $\begin{array}{c}\text { ADK } 500100 \\
\text { kg/ha }\end{array}$ & $176 / 163$ & $177 / 157$ & $156 / 148$ & $170 / 156$ & 32,8 \\
\hline $\begin{array}{l}\text { Risilika } 100 \\
\text { kg/ha }\end{array}$ & $183 / 166$ & $178 / 156$ & $161 / 152$ & $174 / 158$ & 32,8 \\
\hline $\begin{array}{c}\text { Risilika } 250 \\
\text { kg/ha }\end{array}$ & $174 / 170$ & $182 / 160$ & $162 / 153$ & $173 / 161$ & 33,0 \\
\hline $\begin{array}{c}\text { Risilika } 500 \\
\text { kg/ha }\end{array}$ & $175 / 174$ & $181 / 163$ & $166 / 156$ & $174 / 164$ & 33,4 \\
\hline $\mathrm{LSD}_{05}$ & $8 / 8$ & $6 / 7$ & $7 / 8$ & - & 0,3 \\
\hline
\end{tabular}

According to the data in Table 2, a low level of silicon deficiency was observed in the soil of the experimental field, which practically should not affect the formation of the sugar beet yield. However, taking account of the fact that sugar beet is a silicon-loving crop, its silicon nutrition is of great importance. Judging by the results of the study, when experimental fertilizers were used during the growing season of the crop, a higher level of available silicon was maintained in the topsoil, which undoubtedly had a positive effect on the formation of the yield of sugar beet roots and their quality. This is the direct effect of silicon on the crop yield. In addition, as mentioned above, the beneficial effect of siliconcontaining preparations on the productivity of crops is due to the positive effect of silicon on the properties of the soil, in this case, on its nutritional regime. 


\subsection{Yield and quality of sugar beet roots}

The yield of agricultural crops is determined by many interacting factors such as heat, moisture, air and, most importantly, the nutrition of plants with all elements in their optimal ratios and quantities in accordance with the characteristics and needs of the cultivated plant. Table 3 shows the yield and quality indicators of the roots of sugar beet.

Sugar beet is one of the most highly productive agricultural crops, capable of forming up to 90-95 t / ha of roots and about $95 \mathrm{t} /$ ha of tops. The decisive factor in this (along with weather conditions) is balanced plant nutrition, which is ensured by the application of appropriate fertilizers.

Table 3. Yield and quality of roots.

\begin{tabular}{|c|c|c|c|c|c|c|}
\hline \multirow{2}{*}{ Option } & \multirow{2}{*}{ Yield, t/ha } & \multirow{2}{*}{$\begin{array}{c}\text { Dry matter, } \\
\%\end{array}$} & \multicolumn{4}{|c|}{ In natural substance } \\
\hline & & & sugar, $\%$ & $\begin{array}{l}l \text {-amino- } \\
\text { nitrogen, } \\
\text { mol/100 g }\end{array}$ & $\begin{array}{c}\text { potassium, } \\
\mathrm{mol} / 100 \mathrm{~g}\end{array}$ & $\begin{array}{l}\text { nitrate, } \\
\mathrm{mol} / 100 \mathrm{~g}\end{array}$ \\
\hline Control & 24,53 & 24,23 & 17,1 & 1,69 & 4,84 & 0,91 \\
\hline $\begin{array}{c}\text { ADK } \\
100 \\
\mathrm{~kg} / \mathrm{ha}\end{array}$ & 27,85 & 24,78 & 17,8 & 1,53 & 4,82 & 0,87 \\
\hline $\begin{array}{c}\text { ADK } \\
250 \\
\mathrm{~kg} / \mathrm{ha}\end{array}$ & 28,65 & 25,10 & 18,3 & 1,43 & 4,78 & 0,80 \\
\hline $\begin{array}{c}\mathrm{ADK} \\
500100 \\
\mathrm{~kg} / \mathrm{ha}\end{array}$ & 31,05 & 25,20 & 18,4 & 1,38 & 4,79 & 0,76 \\
\hline $\begin{array}{c}\text { Risilika } \\
100 \\
\mathrm{~kg} / \mathrm{ha}\end{array}$ & 26,45 & 25,18 & 18,4 & 1,60 & 4,82 & 0,825 \\
\hline $\begin{array}{l}\text { Risilika } \\
250 \\
\mathrm{~kg} / \mathrm{ha}\end{array}$ & 28,03 & 25,55 & 18,8 & 1,45 & 4,76 & 0,72 \\
\hline $\begin{array}{l}\text { Risilika } \\
500 \\
\mathrm{~kg} / \mathrm{ha}\end{array}$ & 29,28 & 25,50 & 18,7 & 1,40 & 4,71 & 0,71 \\
\hline $\mathrm{LSD}_{05}$ & 1,40 & 0,55 & 0,5 & 0,13 & 0,09 & 0,06 \\
\hline
\end{tabular}

The low yield of sugar beet in the experiments is primarily due to the unfavorable growing conditions (as mentioned above) in the year of the experiments. However, the tested silicon-containing preparations contributed to a statistically reliable increase in crop 
productivity through the optimization of plant nutrition. At the same time, the yield of sugar beet roots in the control option was $24.53 \mathrm{t} / \mathrm{ha}$, the use of ADK provided its increase from 3.23 to $6.52 \mathrm{t} /$ ha (14-27\%), Risilika - from 1.92 to $4.75 \mathrm{t} /$ ha $(8-19 \%)$. It should be noted that the higher the dose of the preparation, the higher the yield, but not proportional to it. The yield increase is higher when ADK (amorphous silicon dioxide) was used as a fertilizer by an average of $1.11 \mathrm{t} / \mathrm{ha}$. Apparently, due to a high soil supply with phosphorus and potassium, the higher content of silicon in ADK and, therefore, in the soil solution was of greater importance. Sugar beet, as noted above, is one of the most silicon-loving crops.

It follows from the research results that the production of sugar beets when grown on leached chernozems with a high supply of phosphorus and potassium is of good quality for sugar production. The use of silicon-containing preparations in the cultivation technology contributed to an increase in the main indicator of the quality of sugar beet roots - the sugar (sucrose) content. The latter increased from $17.1 \%$ in the control to $18.8 \%$ (the option with the use of Risilika at a dose of $250 \mathrm{~kg} / \mathrm{ha}$ ), which makes it possible to additionally obtain more than $500 \mathrm{~kg}$ of sugar per hectare.

Our studies confirm similar literature data [16-17]. At the same time, the authors believe that silicon fertilizers affect biochemical processes during the period of fruit formation and lead to an increase in their quality, first of all, to an increase in their sugar content. In addition, there is a hypothesis that monosilicic acid participates in the synthesis of sucrose itself [17].

The content of potassium which is one of the molasses formers in sugar beet roots belongs to important technological indicators. The higher this indicator, the lower the quality of sugar beets. In the experiments, the potassium content in sugar beet roots decreased from $4.84 \mathrm{mmol} / 100 \mathrm{~g}$ of wet weight in the control option to 4.71 when using silicon-containing preparations (Risilika). Sodium is also a molasses former, the content of which impairs the extraction of crystallized sugar. The results of the study showed that the sodium content in roots decreased according to the options of the experiment relative to the control one.

The most harmful molasses former is alpha-amino nitrogen, which plays a negative role in sugar extraction. On average, the content of alpha-amino nitrogen in sugar beet roots also decreased when using the silicon-containing preparations ADK and Risilika as fertilizers.

\section{Conclusions}

1. Silicon-containing preparations ADK (amorphous silicon dioxide) and Risilika (pyrolysate of rice husks and straw), used as fertilizers for sugar beets, contributed to maintaining the nutrient regime of the soil (content of nitrogen, phosphorus, silicon in an accessible form) at a higher level, despite intensive uptake of nutrients for the formation of the yield of roots.

2. Both preparations, applied in different doses $(100,250,500 \mathrm{~kg} / \mathrm{ha})$, had a positive effect on the productivity of sugar beet. Depending on the doses of the preparations, the yield increase ranged from 3.32 to $6.52 \mathrm{t} /$ ha $(17-27 \%)$ when ADK was used as a fertilizer and from 1.92 to $4.75 \mathrm{t} /$ ha $(8-19 \%)$ with Risilika. The yield of crops was higher with an increase in the amount of preparations, but disproportionately to the doses used.

3. Silicon-containing preparations contributed to the improvement of produce quality. Thus, the main indicator of the quality of sugar beet roots - sugar content - with the use of ADK increased by $0.7-1.3 \%$ and amounted to $18.4 \%$ at a dose of $500 \mathrm{~kg} / \mathrm{ha}$, Risilika at the same dose to $18.8 \%$ (control option to $17,1 \%$ ). The latter makes it possible to additionally obtain more than $500 \mathrm{~kg}$ of sugar from each hectare of arable land. The content of potassium, sodium and alpha-amino nitrogen decreased in roots. 


\section{References}

1. Voronkov M G, Zelchan G I, Lukevich AYu 1978 Silicon and life (Riga: Zinatne) p 587

2. Samsonova N Ye 2005 Silicon in soil and plants Agrochemistry 6 76-86

3. Samsonova N Ye 2019 Silicon in plant and animal organisms Agrochemistry 1 86-96

4. Bocharnikova E A, Matychenkov V V, Matychenkov M V 2011 Silicon fertilizers and ameliorants: history of study, theory and practice of application Agrochemistry 7 84-96

5. Kulikova $\mathrm{A} \mathrm{Kh} 2013$ Silicon and high-siliceous rocks in the fertilization system of agricultural crops (Ulyanovsk) 176

6. Tisdale S L, Nelson W L, Beaton J D, Havlin J L 1993 Soil fertility and fertilizers (New York: Macmillan) p 634

7. Casey W H, Kinrade S D, Knight C T G, Rains D W, Epstein E 2004 Aqueous silicate complexes in wheat, Triticum aestivum L. Plant Cell Environ 27 51-54

8. Ma I F, Yamaji N 2006 Silicon uptake and accumulation in higher plants Trends Plant Sci. 11 392-397

9. Meyer I H, Keeping M Q Impact of silicon in alleviating biotic and abiotic stress in sugarcane: a review (www. siliforce.com)

10. 2017 State catalog of pesticides and agrochemicals permitted for use in the Russian Federation Part 1 (Moscow) p 936

11. Landberg T, Areger M 2017 Silicon nanoparticle effects on arsenic and cadmium plant uptake // $7^{\text {th }}$ Inter. Conf. Silicon Agricult. Proced. Abstracts. India p 68

12. Greger M, Landberg T, Nazaralion S 2017 Plant uptake of silicon nanoparticles $7^{\text {th }}$ Inter. Conf. Silicon Agricult. Proced. Abstracts. India p 40

13. Gladkova K F 1982 The role of silicon in phosphate nutrition of plants Agrochemistry №2 133-144

14. O-Relly S E, Sims I T 1995 Phosphorus adsorption and desorption in a sandy soil amended with high rates of coal fly ash Com. Soil Sci. Plant Anal 26(17-18) 2983-2993

15. Nortveat I I 1986 Effect of calcium silicate slag application on sodium - 226 concentrations in plant tissues Com. Soil Sci. Plant Anal 17(1) 75-84

16. Matichenkov V V, Bocharnikova E A 2004 Si in horticulture industry Plant Mineral Nutrition and Pesticide management 2 ed Drisl., S M Tain 217-228

17. Ma I F, Takahashi E 2002 Soil, fertilizer and plant silicon research in Japan (The Amsterdam: Elsevier) p 215 